\title{
Tee Device
}

National Cancer Institute

\section{Source}

National Cancer Institute. Tee Device. NCI Thesaurus. Code C50210.

A device designed to be used for transesophogeal echocardiogram (TEE). 